\title{
Research on the Construction of Innovation and Entrepreneurship Training System in Financial and Economic Colleges
}

\author{
Hui Shang \\ School of Food Science and Engineering, Nanjing University of Finance \& Economics, Nanjing \\ 210023, China. \\ sh8506@126.com
}

Keywords: Finance and economics, university, innovation and entrepreneurship, construction.

\begin{abstract}
This article begins with the current situation of innovation and entrepreneurship education in China for more than a decade, analyzes the existing problems and deficiencies, compares the practical experience of other universities in China, explores ideas for the innovation and entrepreneurship education system in finance and economics colleges, and constructs a series of safeguard measures, improve the effectiveness of innovation and entrepreneurship training in financial and economic institutions.
\end{abstract}

\section{Introduction}

Innovation and entrepreneurship education is a hot topic of education in China in recent years. It originally originated in the United States and was later recognized and respected by many countries around the world. At the 1989 International Education Conference, the three major education programs in the 21st century were formally designated as professional education, vocational education, and innovation and entrepreneurship education. In the new century, China will increase its emphasis on innovation and entrepreneurship education, strive to build an innovative country, accelerate reforms in the education field, and enhance China's cultural soft power. In order to promote the development of innovation and entrepreneurship education, the General Office of the Ministry of Education and the General Office of the Ministry of Science and Technology formally issued the "Approval Measures for the Practice Base for University Students' Technology and Entrepreneurship (Trial)" in April 2010, and then in May 2010 issued The "Opinions on Vigorously Promoting Innovation and Entrepreneurial Education in junior high school and Self-starting Work for College Students", showing that our government has given very high attention to innovation and entrepreneurship education.

\section{The Necessity of Constructing Innovation and Entrepreneurship Training System in Colleges and Universities}

\subsection{The Need for World Economic Change.}

Today's society values knowledge and talents. In the modern global economy, the most important core competitiveness is intellectual property, knowledge innovation, and the attraction and application of talents and knowledge. "Talent is the primary productive force." Today, with modernization, new talents with innovative spirit and entrepreneurial ability are the engines that promote the continuous progress of the economic, political, and cultural world. Especially in China, which is in the development stage, the sense of innovation is particularly important, and talented people with innovative ideas are particularly critical. Higher education institutions are the cradle of cultivating talents, and they also put cultivating innovative talents as their goals. Therefore, they need to innovate and establish education models and systems for higher education institutions, and cultivate the high-quality talents needed by society.

\subsection{Increased Employment of College Students Causes Higher Employment Pressure.}

Since the 20th century in China, the scale of enrollment in universities has been continuously expanding, made the number of university graduates continuous increase. This has led to an increase 
in the difficulty of employment. Under the background of the unchanging economic conditions and external economic environment in China, the more the graduated, the more difficult the employment will be. The problem of "graduation and unemployment" is not only the most concerned problem for college students, but also the common concern of the whole society. For many families, a university student truly represents the hope of the entire family. Many parents still imagine that their children will get a secure job when they graduate from college. Today, the severe employment situation will not only make students' confidence frustrated and it is difficult to realize its own self-worth. It will also lead to instability in the family. It will also hinder the development of higher education institutions, and it will bring negative effect to sustainable development and harmony stability of the entire society. In the face of such a severe employment situation, college students are encouraged to use their own advantages and the ability to accept new things quickly in order to innovate and start their own businesses. This will contribute to the solution of China's employment problems. This innovative and entrepreneurial ability requires specialized education and further training in universities. The purpose of education in universities and colleges is not only to teach students knowledge and professional skills, but more importantly, through the study of students' basic knowledge, to form their own learning system and thinking mode, and then have the ability to innovate their own business R\&D. The advancement of science and technology and the development of society are inseparable from innovation. The endless stream of advanced technologies and knowledge concepts must be based on innovation. Students can improve their knowledge and ability through the training and integrate their knowledge into real productivity and wealth. The introduction of innovation and entrepreneurship education in higher of higher is precisely the driving force for accelerating the transformation of knowledge into productivity and the continuous development of social and economic.

\subsection{The Inevitable Demands of Implementing Deepening Reform in College Innovation and Entrepreneurship Education.}

On May 13, 2015, the "General Office of the State Council on Implementing Opinions on Deepening the Reform of Innovation and Entrepreneurship Education in Colleges and Universities" was published. It was pointed out that since 2015, colleges and universities have paid full attention to innovation and entrepreneurship education and deepened reforms and In 2017 get breakthrough victory, building into a scientifically advanced, innovative and entrepreneurial education model with Chinese characteristics, having a large number of replicable and scalable results, and widely promoting innovation and entrepreneurship education in the entire education field, providing excellent conditions for the entrepreneurial planning of college students and helping them achieve Business goals. 1By 2020, we must comprehensively improve the innovation and entrepreneurship education system in institutions of higher learning such as classroom teaching, self-directed learning, practical integration, support and guidance, and cultural leadership. We must comprehensively improve the overall quality of talents in the new century so that students' abilities and awareness in innovation and entrepreneurship will be improved. As early as 2002, colleges and universities started their innovation and entrepreneurship education programs. Tsinghua University, Renmin University of China, Beijing University of Aeronautics and Astronautics and other 9 famous schools have become the earliest pilot institutions for the development of innovation and entrepreneurship education. 2So far, innovation and entrepreneurship education has been widely promoted, and more and more universities have set up innovation and entrepreneurship education as formal learning courses. The development of innovation and entrepreneurship education has made remarkable progress. However, we also found that most of the successful teaching cases for entrepreneurial innovation are scientific and technological innovations. As a finance and economics institution, science and technology are not the strengths of such schools, so such institutions should vigorously support the development of innovation and entrepreneurship education activities in order to highlight the importance of siege. It also stimulates the establishment of students' awareness of innovation and transforms innovative ideas into entrepreneurial plans in a timely manner. The development of entrepreneurship and innovation education has a long way to go and needs unremitting efforts. 


\section{An Analysis of the Problems in the Process of Innovation and Entrepreneurship Training in Universities}

\subsection{Innovation and Entrepreneurship Education Lags Behind.}

The time for the development of innovation and entrepreneurship education in our country is still very short. Most colleges and students do not have a clear concept for it. The understanding of its meaning is not yet in place. We randomly interviewed some senior students and teachers in school and on campus, discovering that the reasons behind the idea of innovation and entrepreneurship education are mainly the following: First, many students believe that although the school attaches great importance to innovation and entrepreneurship, teachers who have established innovative entrepreneurship courses have also conducted multiple selections. However, due to the limitation of the nature of work, most teachers only stay in the teaching of theoretical knowledge for students, neglecting the improvement of the overall quality of innovation and entrepreneurship, little practice or formalism prevailing. The coverage of entrepreneurship education is not in place, and it is difficult to achieve the ultimate goal of truly enhancing the comprehensive ability of students for innovation and entrepreneurship. Second, most students and teachers do not fully understand the meaning and positive impact of innovation and entrepreneurship education, and simply believe that innovation and entrepreneurship education is simply teach students how to create " Secretary" or "overthrowing the tradition", misunderstood the demand for talents in innovation and entrepreneurship education; third, some people even suggested that innovation entrepreneurship education is meaningless, that entrepreneurial activity should be done after graduating from school, and only the students who not get work will embark on the road to entrepreneurship. This view completely misinterprets the concept of innovation and entrepreneurship education. It can be seen that the degree of recognition of innovation and entrepreneurship in today's society is not enough. Most students are afraid to take risks and do not dare to try their own business ventures. The society also does not support and understand the students who have ideas for innovation and entrepreneurship, especially understanding in families is not enough.

\subsection{Course Setting Is Affected by Tradition.}

It should be said that after many years of development, innovation and entrepreneurship courses have been greatly enriched, and related practical courses have also received a great deal of attention. However, we should also note that innovation and entrepreneurship education still has many deficiencies in setting curriculum. The performance is as follows: generally speaking, a complete and perfect education and teaching system has not yet been established, and the standardization of innovative education is not strict enough, and it has not been built into a sound teaching curriculum system; in addition, the number of opened innovative entrepreneurship courses is still relatively small, and occupied in entire school teaching structures is relatively small; most of the teaching courses are mainly theoretical courses, practical courses are few and the quality is difficult to guarantee. On the other hand, non-standard textbooks are also an important issue. So far, the Ministry of Education has not yet published a unified teaching material for innovation and entrepreneurship. The teaching materials used in most colleges and universities are compiled by the school itself. The consequence of this is that the teaching effectiveness of innovative and entrepreneurial courses is not standardized and the effect is not ideal. Therefore, to further develop innovation and entrepreneurship education, we must improve the curriculum structure, arrange innovation and entrepreneurship education in daily teaching, and create a strong atmosphere of innovation and entrepreneurship education on campus. This will not only improve students' theoretical foundation for innovation, but also can enhance the ability of innovation and entrepreneurship, and inspire students' passion for entrepreneurship.

\subsection{Weak Faculty and Practical Experience Lacking.}

Innovation and entrepreneurship education is in a period of initial development in our country. The role of teachers is particularly important. Only when teachers have the sense of creating innovation can we lead and cultivate students' abilities and awareness in innovation and entrepreneurship. However, on the whole, the number of innovation and entrepreneurship teachers in 
China is short, and teachers' experience is insufficient. Many teachers are professional teachers, and some are teachers working in student work. Their major is to study other topics and lack the practical experience of innovation and entrepreneurship. They are not specialized in learning and research in this area, they do not form a complete knowledge structure, and they do not even have the ability to practice guidance. This leads them to lecture on the subject at the time of the lecture, and the theory and practice are not even connected. Even theoretical knowledge cannot be explained clearly. Therefore, the lack of teacher resources, coupled with a single teaching method and content, the innovation and entrepreneurship education teachers must be rectified, otherwise it is difficult to achieve the goal.

\subsection{Students' Motivation to Learn Is Not High.}

Judging from the overall situation in our country, the success rate of college students' entrepreneurial success is still relatively low. This is caused by many factors, such as knowledge structure, practical experience, awareness of thinking patterns, and ability. Take a financial institution as an example. Only about $1 \%$ of the students will embark on the road to self-employment after graduation each year. Of course, few succeed at the end. In contrast, the proportion of start-ups in U.S. college students is about 30\%, and in Japan about 18\%. From these results, we can see that the gap between the innovation and entrepreneurship rate of Chinese college students and the Western countries is still very large.

As far as the current situation is concerned, China's entrepreneurial innovation education mainly focuses on theoretical teaching in the classroom. Although some innovative and entrepreneurial practices have also been carried out, the majority of activities are formal and the effects of the activities are not ideal. The situation is that within the school organizations usually organize innovation entrepreneurship lectures, training classes, and entrepreneurship planning book contests. There are not many students involved. Because of restrictions on training bases, only some students have the opportunity to conduct practices, so innovation and entrepreneurship Education is still confined to "on paper". Some students did not attach enough importance to innovation -entrepreneurship -related courses. They believed that it is unnecessary to start their own business and at the same time lack of confidence and preparation.

\section{Tentative Ideas on Constructing Innovation and Entrepreneurial Education System in Financial and Economic Colleges}

Cultivating high-quality and innovative talents is a general goal of innovation and entrepreneurship education in colleges and universities. The core issue of innovation and entrepreneurship education is "cultivating what kind of talents". Although the teaching philosophy is novel, it is essentially the same in nature as traditional education. The orientation of personnel training in colleges and universities is the same. It is consistent with the goals of the university's overall education planning.

\subsection{Strengthen the Process of Innovation and Entrepreneurship Education.}

The design of innovation and entrepreneurship education model and teaching process must firstly undertake the characteristics of the university's own education, combine professional education with innovation and entrepreneurship education, and cultivate students' comprehensive application abilities and professional disciplines. In the curriculum setting of innovation and entrepreneurship education, it should be defined as a compulsory course for students, and credits should be included in the course to enhance students' learning of the innovation and entrepreneurship curriculum. Secondly, innovation and entrepreneurship education should take the path of linking production, education, and research. The university's innovation and entrepreneurship education base is the platform for realization. It is not just a link between the theoretical knowledge of innovation and entrepreneurship, but also a combination of professional knowledge and practical knowledge. Achieve integration of teaching, research, practice and incubation. Thirdly, establishing an operation system for innovation and entrepreneurship practice and building a complex practical teaching base so that each student can practically practice. In addition, relying on outdoor school specific practices, strengthening the 
collaboration between schools and enterprises, and exploring the training platform for off-campus training are also important.

\subsection{Strengthen Service Support for Innovative Entrepreneurial Education.}

\subsubsection{Cultivate Entrepreneurial Culture, Rooting in the Spirit of Innovation.}

Cultural constraints are extremely extensive, and role models have infinite power. Through all means of publicity, the great charm of innovation and entrepreneurship education is demonstrated in various steps, both inside and outside the classroom, at home, and in school. In addition, it is also possible to establish a model for actively innovating entrepreneurship, encourage students to support innovation and entrepreneurial success, and encourage students to establish lofty pursuits, demonstrate individuality, encourage aggressive innovations, and actively innovate. Then the innovation atmosphere can be gradually established.

\subsubsection{Establish a Full-Time Innovation and Entrepreneurship Education Management Agency.}

Schools should establish good long-term partnerships with enterprises, and they can obtain support about innovative venture capital funds and provide practical opportunities for their students. They should also contact successful alumni. They can teach their experience in innovation and entrepreneurship to graduates. In addition to the efforts to develop off-campus resources, universities should also start from within the university and establish full-time management institutions, being responsible for student innovation and entrepreneurial work, so that the coverage of innovation and entrepreneurship education is constantly increasing. Expanding until the whole school is covered.

\subsubsection{Strengthen the Training of Teachers.}

To improve students' the innovation and entrepreneurial thinking, teachers' guidance is highly needed, to teach the content of innovation and entrepreneurship as the prerequisite, to enhance the level of innovation and entrepreneurship as the core, and to cultivate the concept of innovation and entrepreneurship as the key to innovation and entrepreneurship.

Setting required courses, simulating entrepreneurial start-up practices, and propagating entrepreneurial achievements, setting up an immersive teaching environment, students can grasp fundamental procedures and measures, find out relevant policies and regulations. It is necessary to build a team of innovation and entrepreneurship teachers. On the whole, at present, there is a shortage of resources for college teachers in China who are professional and have some experience in innovation and entrepreneurship.

\subsection{Improve the Evaluation Mechanism for Innovation and Entrepreneurship Education.}

The innovation and entrepreneurship education system project in colleges is affected by many factors. In order to make a reasonable assessment of the effectiveness of innovation and entrepreneurship education, according to the characteristics, goals, and content of innovation and entrepreneurship education in colleges and universities, and in combination with the characteristics of students, it is necessary to focus on evaluation indexes including Evaluation indicators, corporate evaluations, government evaluations, and social assessments.

The purpose of innovation and entrepreneurship education is not just "employment”. Its core idea is to "create new jobs initiatively." Under the guiding ideology of "starting business to promote employment”, innovation and entrepreneurship education in universities cannot be limited to helping students find jobs. Instead, it is necessary to cultivate innovative talents with pioneering and innovative spirit for the society. This not only has a positive impact on the development of students' careers, but also has positive significance for the development of the country and society.

\section{Acknowledgments}

The research is supported by the Teaching Reform Research Project of Nanjing University of Finance and Economics (Grant No. JGY1743), the Top-notch Academic Programs Project of Jiangsu Higher Education Institutions (Grant No. PPZY2015B152). 


\section{References}

[1]. Jasso Lei. Analysis on Innovation and Entrepreneurship Education at Home and Abroad. Science and China Youth Technology. Vol. 14 (2007) No. 2, p. 26-28.

[2]. Wei Huang. The Subjectivity Education Theory: the Philosophy of Education. Educational Research. Vol. 9 (2002) No. 4, p. 74-77.

[3]. Wei liu. Thoughts of Construaction on Personnel Cultivating System of Innovation-enterpreneurship Education in Colleages and Universsities. Education Science. Vol. 27 (2011) No. 5, p. 64-67.

[4]. Quinten Li. Review of Schumpeterian Innovation and Entrepreneur Thought and its Prevalence. Science of Science and Management of S. \& T. Vol. 26 (2005) No. 5, p. 76-81.

[5]. Shining Dong, Shaping Gong. Social Involvement: Construction on Open Innovation-enterpreneurship Education Pattern in Colleages and Universsities. China Higher Education Research. Vol. 26 (2010) No. 2, p. 127-128.

[6]. Xiaohui Yang. Entrepreneurship Education and the Innovation Talent Cultivation in Colleges and Universities of China. China Higher Education Research. Vol. 31 (2015) No. 1, p. 39-44.

[7]. Shania Li. Construction of Innovation-enterpreneurship Education System for College Students. Heilongjiang Researches on Higher Education. Vol. 30 (2011) No. 9, p. 119-121.

[8]. Jun Li, Xiao hen Du, Yuan Liu. Research on Entrepreneurship Education Pattern in Universities of Financial and Economics. China Electric Power Education. Vol. 26 (2010) No. 31, p. 8-10. 